\title{
高解像度血管撮影装置による中枢性血管性疾患の血管解剖の分析
}

\author{
佐藤 慎祐 ${ }^{12)}$ ，新見 康成 ${ }^{12)}$, 久司 一貴 ${ }^{1)}$, 島 彰吾1)2), 劉 美憬 ${ }^{1) 2}$, 井上 龍也 ${ }^{12)}$, \\ 岡田芳和 ${ }^{1)}$ \\ 1）聖路加国際病院脳神経外科，2）同 神経血管内治療科
}

\section{Endovascular Treatment for Pediatric Intracranial and Spinal Arteriove- nous Shunt Disease}

\author{
Shinsuke Sato, M.D. ${ }^{1) 2}$, Yasunari Niimi, M.D. ${ }^{12)}$, Kazuki Kushi, M.D. ${ }^{1)}$, Shougo Shima, M.D. ${ }^{12)}$, \\ Bikei Ryu, M.D. ${ }^{1) 2}$, Tatsuya Inoue, M.D. ${ }^{\left.1{ }^{2}\right)}$, and Yoshikazu Okada, M.D. ${ }^{1)}$ \\ 1) Department of Neurosurgery, St Luke's International Hospital, 2) Department of Neuroendovascular Therapy, St Luke's \\ International Hospital
}

Precise assessment of the angioarchitecture of cerebrovascular diseases is important for accurate diagnosis and planning surgical, endovascular, or conservative management to minimize the risk of treatment complications. Recent advancements in angiography techniques have enabled the acquisition of high-quality vascular images, even for small vessels, using rotational angiography and cone-beam CT. It is also possible to precisely assess the relationship between vascular pathology and the surrounding normal vessels or other anatomical structures by developing fusion images with other angiographic images or MRI. For example, before aneurysm treatment, we can preoperatively assess the origin and course of the perforators associated with an aneurysm. For spinal shunt diseases, the shunt point can be precisely identified in relation to the surrounding spinal cord, nerve root, dura, and bony and soft tissue structures. This information is important for accurate diagnosis, understanding of the disease, and treatment planning. Vascular imaging with high-resolution angiography is progressively improving and becoming indispensable for the diagnosis and treatment of cerebrovascular diseases.

(Received June 1, 2021 ; accepted July 6, 2021)

Key words : intracranial aneurysm, spinal arteriovenous shunts, high resolution cone beam CT Jpn J Neurosurg（Tokyo） $30: 639-645,2021$

\section{はじめに}

脳春髄血管疾患の外科および血管内治療における術前 画像診断において，微細な血管構造の把握は正確な診断 と治療方針の決定および術中の合併症リスクを低減させ るために重要である。ここでは，特に脳動脈瘤治療と脊 髄動静脈シャント疾患において, 高解像度血管撮影装置
を用いて作成した slab maximum intensity projection (MIP), fusion MIP, $20 \mathrm{sec}$ DynaCT imaging, さらに他の modality との fusion 画像の役割について概説する。今回 われわれが用いた Siemensの高精度画像収集機能は syngo DynaCT Micro が一般的なピクセルデータの補正 処理による $2 \times 2$ binning マトリックス収集ではなく，ピ クセルデータの補間処理を行わないピクセルオリジナル

\footnotetext{
連絡先：佐藤慎祐，广 104-8560 東京都中央区明石町 9-1 聖路加国際病院脳神経外科

Address reprint requests to : Shinsuke Sato, M.D., Department of Neurosurgery, St Luke's International Hospital, 9-1 Akashicho, Chuo-ku, Tokyo 104-8560, Japan
} 

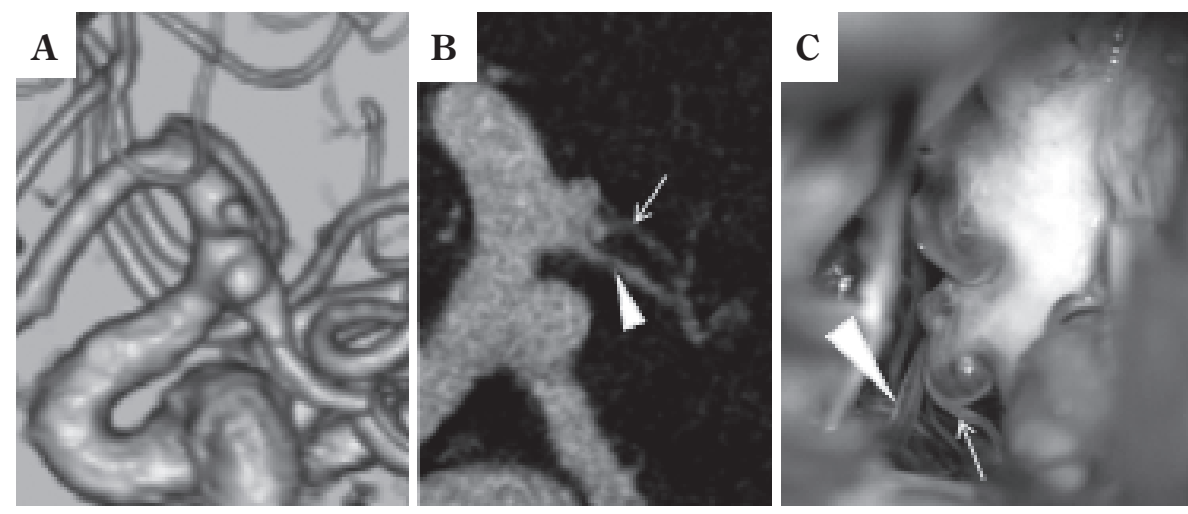

Fig. 1 A case of an anterior choroidal artery aneurysm with a separate perforator

A : Volume rendering (VR) image of the rotational angiogram of the left internal carotid artery showing only the main anterior choroidal artery.

B : Slab maximum intensity projection (MIP) (oblique sagittal slice) showing a separate perforator (arrow) originating from the dome of the aneurysm distal to the main anterior choroidal artery (arrowhead).

$\mathrm{C}:$ Intraoperative view confirming the main anterior choroidal artery (arrowhead) and a separate perforator (arrow).

の $1 \times 1$ binning マトリックス収集が可能となっており， 鮮鋭度に特化した撮影方法と再構成により，より高精細 な cone beam CT (CBCT) 撮影が可能となっている.

\section{脳動脈瘤治療における 高解像度血管撮影装置の利用}

\section{1 前脈絡叢動脈瘤について}

前脈絡叢動脈瘤の外科および血管内治療において，穿 通枝障害はAbbieもしくはMonakow症候群といわれる上 肢優位運動麻痺，半身感覚鈍麻，同名半盲を発症するた め, 微細な穿通枝の分岐位置の術前画像評価が重要であ $3^{122)}$. 解剖学的に穿通枝の分岐は複数本ある場合もあ り, CT angiography（CTA）の volume rendering（VR）画 像では穿通枝の血管径によっては可視化されない場合も ある。われわれは，血管造影装置（Siemens：ArtisQ）, workstation (SyngoX-WP) での slab MIP での評価で, 実 際の前脈絡叢動脈の血管径 $(0.7 \sim 2.0 \mathrm{~mm})$ に準じるスラ イス幅（0.7〜 1 mm 前後）で撮影を行い，術前に重要と なる動脈瘤の母血管, neck や dome から直接分岐する穿 通枝の評価を行っている ${ }^{3)}$. 実際の症例における 3DCTA の VR 画像と slab MIP 画像での分岐血管の本数が異なる 症例を Fig. 1 に示す，VR 画像では特に threshold に影響 されやすく, $1 \mathrm{~mm}$ 以下の最小血管は描出困難になり branch の描出がないが, slab MIP 画像では branch は 2 本 描出しており，明瞭になっていた。 Slab MIP は CBCT と
CTA の両者があるが, 前者の最小厚は $0.5 \mathrm{~mm}$, 後者は, $0.625 \mathrm{~mm}$ (GE health care Japan), $0.5 \mathrm{~mm}$ (Cannon) と なっていて大差ない. しかし CTAでは静脈からの造影で あるため, 撮影夕イミングが好条件であることが前提と なる，高解像度血管造影装置であ孔ば，事前撮影の循環 動態から delay time を適切に選択でき, 高精細な画像診 断が可能となるため, domeから分岐する分岐血管を事 前に把握でき，穿通枝の温存が困難な場合にコイル塞栓 術を回避したり，開頭クリッピング時の closure line を術 前に想定することが可能となる。同様に，解離性椎骨動 脈瘤では dome から分岐する穿通枝の確認においても VR 画像よりも slab MIP 画像のほうが空間分解能が高い ため，血管内治療の際には必須の検査となっている.

\section{脊髄動静脈シャント疾患における 高解像度血管撮影装置の利用}

脊髄動静脈シャント疾患においては, 安全で効果的な 血管内治療を行うためには，正しい春髄血管解剖の理解 と qualityの高い脊髄血管撮影を行うことが基本となる。 術前画像診断の modality として造影 CT, MRI画像では, feeder が複数である場合や栄養血管径が細い場合，神経 根にシャントがある場合にはその空間分解能に限界があ る。春髄血管撮影での回転撮影（5s DSA body, FOV : 22 cm）では，全身麻酔下，無呼吸下が必須であり ${ }^{6)}$, VR や slab MIP の画像の作成, さらに両側撮影または複数の 

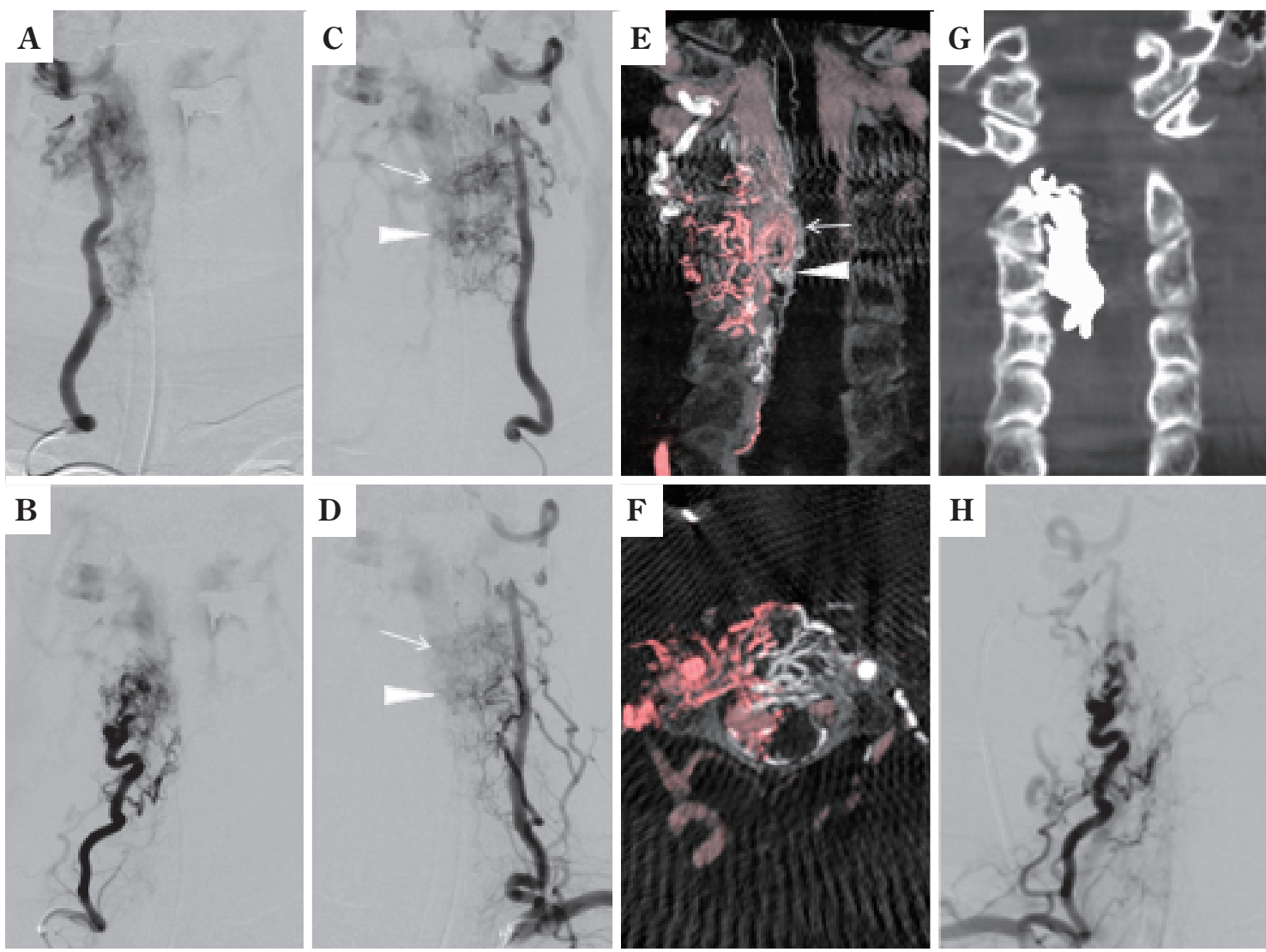

Fig. 2 A case of right spinal epidural arteriovenous fistulas (AVFs)

A-D : PA views of an angiogram of the right vertebral (A), right ascending cervical (B), left vertebral (C), and the left subclavian arteries（D) showing high flow spinal epidural AVFs at the C3 (arrow) and $\mathrm{C} 4$ (arrowhead) vertebral levels.

E : Coronal fusion slab MIP images of the right vertebral artery and the right ascending cervical artery demonstrating epidural AVFs at the $\mathrm{C}_{3}$ (arrow) and $\mathrm{C}_{4}$ (arrowhead) vertebral levels.

F : Axial fusion slab MIP images of the right and left vertebral arteries demonstrating AV shunts only on the right-side.

$\mathrm{G}$ : Coronal cone-beam $\mathrm{CT}$ image showing coils introduced into the $\mathrm{C} 3$ and $\mathrm{C} 4$ epidural venous space by the transvenous approach.

H : PA view of the right subclavian artery after embolization showing complete obliteration of the AVFs. Left-sided injection also showed no residual AVFs.

feeder 間での fusion MIP 画像や, CBCT と MRI の fusion image の作成を行い, 周囲の構造物を含めた血管解剖の 解析を行っている。 またさらに微細なシャントでは, Siemens 高精度画像収集機能の syngo DynaCT Micro の 1 つとして $20 \mathrm{sec}$ DynaCT micro mode で通常の 5 秒よりも 長い時間での撮影や，マイクロカテーテルからの造影剂 注入下での回転撮影を行い, シャント部位の解析を行う 場合もある. 以上のさまざまな $\mathrm{CBCT}$ 撮影方法において は, $300 \mathrm{mgI} / \mathrm{ml}$ の造影剤を使用して直前の血管撮影での 動静脈シャントの循環動態に合わせて, 適切な X-ray delay time を設定している, 以下, 疾患による高解像度 血管撮影装置の利用方法を概説する.

\section{1 资髄硬膜動静脈瘻において}

脊髄硬膜動静脈瘻（spinal dural arteriovenous fistula： SDAVF）は，脊䯣脊椎血管奇形の中で最も頻度が高く， 40 歳以上の中高年男性に好発し, 中下位胸椎から腰椎の 椎間孔近傍の硬膜の膜内に後天的に AV シャントを認め る. 根静脈の貫通部が神経根に沿わない場合が $40 \%$ に存 在し， 2 椎体から栄養を受ける場合があるが，還流静脈 は常に 1 本である。最近は 3DCTA や MRA でシャント部 位の予想が行えるようになってきているが, 時間分解能 は期待できず，空間分解能も十分ではないため脊髄血管 撮影がゴールドスタンダードであることは変わらない. 春髄血管撮影では, 確定診断のほかに, 栄養血管の数, 還流静脈となっている perimedullary vein の血流停滞の 


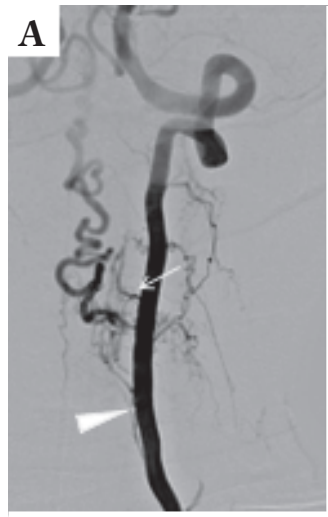

B
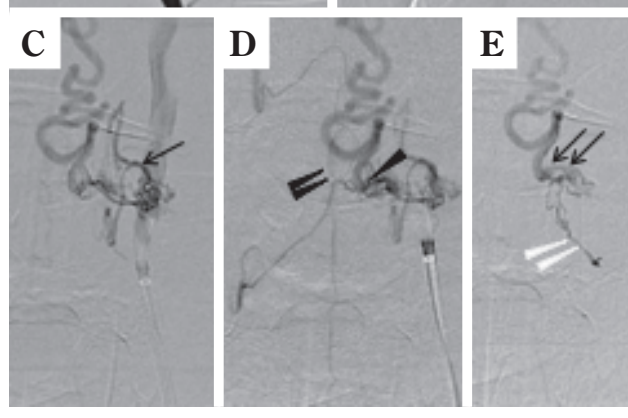

Fig. 3 A case of the left $\mathrm{C} 5$ radicular AVFs

PA (A) and lateral（B) views of the left vertebral angiogram showing radicular AVFs fed by the left C5 (arrow) and $\mathrm{C} 6$ (arrowhead) radiculo-meningeal arteries.

$\mathrm{C}$ : Superselective angiography of the left $\mathrm{C} 5$ radiculo-meningeal artery (arrow) demonstrating the fistula fed by the left $\mathrm{C} 5$ radicular artery.

D : Superselective angiography from the left $\mathrm{C} 5$ radicular artery showing the AVF （arrowhead） and anterior spinal artery (double black arrowheads).

E : Superselective angiography from the left $\mathrm{C} 6$ radiculomeningeal artery (white double arrowheads) showing additional radicular AVFs (double arrows).

F, G : The fusion images of the slab MIP obtained with rotational angiography of the left vertebral artery and T2weighted MRI showing the fistula（white double arrows） along the nerve root outside of the spinal cord.

$\mathbf{H}$ : Intraoperative view from the right-sided approach showing the AVFs on the ventral side of the $\mathrm{C} 5$ nerve root (white double arrows).

I : Intraoperative view after the obliteration of the AVFs by clipping of the draining vein.

程度，前脊骾動脈の還流時間の遅延の程度を評価する。 また SDAVF の栄養血管と同じレベルから前脊髄動脈や 後脊髄動脈などの奉髄血管が出ていないかどうかの情報 は，特に血管内治療を行う際にはきわめて重要である が，通常の血管撮影や回転撮影の VR 画像では解像度が 不十分で, slab MIP 画像による解析が必須である. Slab MIP 画像を用いると, 硬膜のどの部分にシャントが存在 するかが明らかになるし, 通常の血管撮影では気づかな かった複数の栄養血管が明らかになることも多い.われ われの施設では, MRI T2 volume 画像と slab MIP 画像の fusion を利用して実際に硬膜上のどの部分にシャントが あるかどうかを確認している7).

\section{High flow spinal epidural AVFにおける fusion slab MIP 画像の利用}

脊髄硬膜外動静脈瘻（spinal epidural AVF：SEDAVF） は, 脊髄硬膜動静脈瘦と異なり, 還流静脈が硬膜外静脈 であることが前提となり, Kiyosue ら ${ }^{4)}$ は ventral, dorsal, lateral の 3 つに分類し, 多くが ventral にあると報告して いる. Low flowのものは腰椎に好発し, dorsal somatic branchが main feeder となり, 両側性に栄養されることも 多い ${ }^{4)}$. High flowのものは, 頚椎レベルに好発し, シャ ントが両側性の場合もあり，通常の血管撮影のみでは正 確にシャント部位を同定することが難しい場合もあ $ろ^{4)}$. 左右や, 同側の複数の feeder から行った回転撮影 からの slab MIP 画像の fusion を作成することで, 正確な シャント部位診断のみならず, 経静脈的に塞栓術を行う 際にどこまで塞栓すれば根治が可能かどうかを評価する 

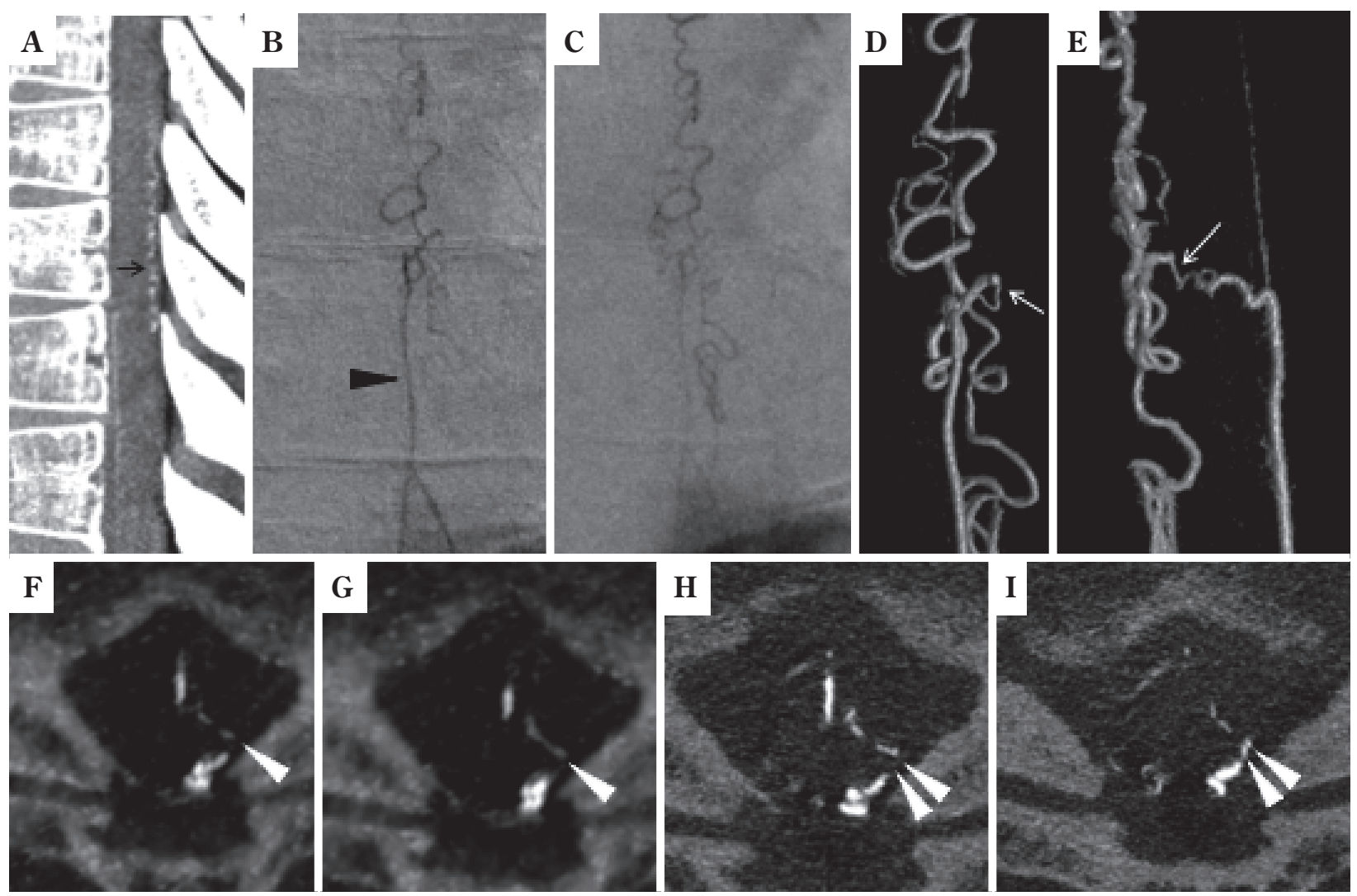

Fig. 4 A case of an AVF supplied by a branch of the anterior spinal artery (ASA)

A : Sagittal view of the contrast-enhanced CT scan showing a dilated perimedullary vein on the dorsal surface of the spinal cord (black arrow).

B, C : PA views of the radiculomedullary artery angiogram for the early（B） and late（C) phases showing an arteriovenous fistula supplied by the ASA (arrowhead in Panel A).

D, E : VR images obtained by rotational angiography for the radiculomedullary artery in PA (D) and lateral (E) views demonstrating a caliber change of the vessel (white arrow).

F, G : Axial slab MIP images obtained by rotational angiography for the segmental artery using $5 \mathrm{~s}$ DSA mode showing a questionable shunt point at the dorsal lateral aspect of the spinal cord (white arrowhead), but the quality of the images is poor.

H, I : Axial slab MIP images obtained by rotational angiography for the radiculomedullary artery using $20 \mathrm{~s}$ DSA mode demonstrating the fistula site (white double arrows) in the dorsal lateral aspect of the spinal cord. The caliber change showed in $\mathbf{D}, \mathbf{E}$ occurred where the sulcal artery penetrates the spinal cord.

ことが可能である。左右の椎骨動脈からの segmental arteryや，左右の鎖骨下動脈からの ascending cervical artery と deep cervical artery からの feeder が多数存在し た high flow SEDAVF の症例を提示する (Fig. 2). この症 例は，同側の椎骨動脈と鎖骨下動脈の slab MIP の fusion 画像を作成して, シャント部位を事前に正確に理解する ことにより, feeder が流入するレベルにおける拡張した ventral epidural space のみにコイルを充塡することで治 癒が可能であった。本症例のような複数の feeder が流入 する high flow SEDAVF では, coronal fusion MIP 画像が 有用である。

\section{3 㐱髄神経根動静脈瘻（radicular AVF）}

Radicular AVF は, 動静脈シャントが神経根に沿って存 在する. Segmental arteryからの radiculomeningeal artery ないし, 前奉髄動脈や後奉髄動脈の奉髄血管が栄養血管 となるが，両方からの栄養血管を受けたり，シャント部 位が複数ある場合もあり, 通常の血管撮影単独では正確 な血管解剖の解析が困難な場合も多く, シャント部位と 神経根との位置関係もわかりにくい. 回転血管撮影の slab MIP 画像と MRI T2 強調画像との fusion 画像を解析 すれば，より正確な血管解剖の解析が可能になるばかり でなく, 脊髄や神経根とシャント部位との位置関係が把 握でき，治療方針の決定にきわめて有用である．Fig. 3 
に提示する症例では, これらの方法に加えて, microcatheterからの撮影を行い, radiculomeningeal artery と前脊 髄動脈の pial branch などの詳細な血管解剖を解析して, 脊髄前根の radicular AVF と診断し,さらにその詳細な血 管解剖を解析した。それを open surgeryで確認し, 神経 根背側にあるシャント部をクリップで閉鎖した.

\section{4 脊䯣動脈から栄養される動静脈シャント疾患}

春髄動脈が feeder となる動静脈シャント疾患には, spinal cord AVM, perimedullary AVF, radicular AVF があ り, 䅡髄レベルでは, 脊髄動脈が dural AVF や epidural AVF に関与する例も報告されている3). これらの症例に 対しても, 回転血管撮影から得られる slab MIP 画像やそ れらと MRIの fusion 画像の解析はきわめて有用である. ここでは, 通常の血管撮影では詳細な血管構造の把握が 困難であった前脊髄動脈から栄養される微小動静脈シャ ントに対する診断アプローチを紹介する。この症例に対 して, まずT10 segmental artery から 5 秒回転血管撮影を $0.8 \mathrm{ml} / \mathrm{s}$, 総投与量 $8.4 \mathrm{ml}$, delay time を 4 秒で撮影し, $1 \mathrm{~mm}$ スライスで slab MIP 画像を作成した (Fig. 4). し かし, 空間解像度が十分でなく, feeder と drainerの連続 性が不明瞭で shunt pointが正確に同定できなかった。次 に, radiculomedullary artery $へ 1.2$ Fr Magic FM microcatheter を誘導し, 直接マイクロカテーテルからの造影で $20 \mathrm{sec}$ CBCT micro mode で撮影したところ, 明瞭に シャントを描出することができた（Fig. 4)。脊髄背外側 表面で微小動静脈瘻を形成していると判断し, open surgeryで直接クリップによる遮断を行い根治することが できた.

\section{まとめ}

近年の高解像度血管撮影装置の進歩により, 脳脊䯣血 管疾患における微細な血管構造の解析が可能になった。 動脈瘤においては, 回転血管撮影の slab MIP 画像によ り, 術前に瘤周辺の詳細な穿通枝の検討が可能となり, 春髄硬膜動静脈瘻に関しては, 通常の血管撮影で不明瞭 な脊髄動脈が slab MIP 画像で描出される場合があるの で, 術前診断に slab MIP 画像の解析が強く推奨される. また, 複雑な脊髄シャント疾患においては, MIP slab image や MRI との fusion 画像を用いることにより, 春 髄, 神経根, 硬膜, 骨などとシャント部位の正確な位置 関係が把握でき，正確な診断と安全で有効な治療方針の 決定が行えるようになった。 今後, ますます血管撮影装 置の性能が高まり, その診断と治療における重要性が増 すものと思われる。 今後 4DDSA の登場により自由な角 度で, 造影剂の時間的移動状況の解析が可能になり, シャント疾患の血行動態の分析にさらに貢献するものと 考える.

COI

著者全員は日本脳神経外科学会への COI 自己申告の登録を 完了しています。本論文に関して開示すべきCOI はありませ ん

\section{文 献}

1) Friedman JA, Pichelmann MA, Piepgras DG, Atkinson JL, Maher CO, Meyer FB, Hansen KK : Ischemic complications of surgery for anterior choroidal artery aneurysm. J Neurosurg 94:565-572, 2001.

2) Heros RC: Microneurosurgical management of anterior choroidal artery aneurysms. World Neurosurg 73:459$460,2010$.

3) Hiramatsu M, Sugiu K, Ishiguro T, Kiyosue H, Sato K, Takai K, Niimi Y, Matsumaru Y : Angioarchitecture of arteriovenous fistula at the craniocervical junction: a multicenter cohort study of 54 patients. J Neurosurg $\quad 128$ : 1839-1849, 2018.

4) Kiyosue H, Matsumaru Y, Niimi Y, Takai K, Ishiguro T, Hiramatsu M, Tatebayashi K, Takagi T, Yoshimura S ; JSNET Spinal AV Shunts Study Group: Angiographic and clinical characteristic of thoracolumbar spinal epidural and dural arteriovenous fistula. Stroke 48: 3215-3222, 2017.

5) Lehecka M, Dashti R, Laakso A, van Popta JS, Romani R, Navratil O, Kivipelto L, Kivisaari R, Foroughi M, Kokuzawa J, Lehto H, Niemelä M, Rinne J, Ronkainen A, Koivisto T, Jäs̈selainen JE, Hernesniemi J : Microneurosurgical management of anterior choroid artery aneurysms. World Neurosurg 73: 486-499, 2010.

6) Prestigiacomo CJ, Niimi Y, Setton A, Berenstein A: Threedimensional rotational spinal angiography in the evaluation and treatment of vascular malformations. AJNR Am J Neuroradiol 24: 1429-1435, 2003.

7) Ryu B, Sato S, Takase M, Mochizuki T, Shima S, Inoue T, Okada Y, Niimi Y : Diagnostic accuracy of three-dimensional-rotational angiography and heavily $\mathrm{T} 2{ }^{-}$weighted volumetric magnetic resonance fusion imaging for the diagnosis of spinal arteriovenous shunts. J Neurointerv Surg $\mathbf{4}$ : neurintsurg-2020-017252, 2021. 
要

高解像度血管撮影装置による中枢性血管性疾患の血管解剖の分析

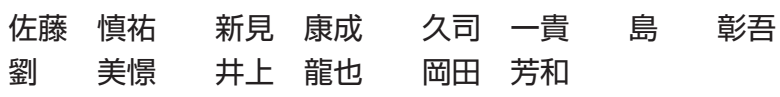

脳脊䯣血管疾患の画像診断において, 微細な血管構造の把握は, 正確な診断のみならず, 外科治 療・血管内治療・保存的加療を含めた治療方針の決定や術中の合併症リスクを低減させることにおい て重要である. 近年の高解像度血管撮影装置の進歩はめざましく, cone beam CT, さらにこれらの 画像同士，または MRI との fusion 画像を用いることにより，脳動脈瘤においては，術前に瘤周辺の 穿通枝の正確な分岐位置の把握, 評価が可能である. また脊髄動静脈シャント疾患では, 脊䯑道, 神経 根, 硬膜, 骨などとシャント部位の正確な位置関係が把握でき, 診断と病変の理解, 治療方針の決定 にも有用である。

脳外誌 $30 ： 639-645,2021$ 